\title{
Origin of Asymmetric Symplectitic Texture in Mantle Xenoliths from the Fangshan Basalt, Eastern China
}

\author{
Donggao Zhao
}

Department of Geological Sciences, Jackson School of Geosciences, University of Texas at Austin, Austin, TX 78712, USA.

Mantle-derived xenoliths brought to the Earth's Surface by basalts are important windows to understand composition, evolution and processes of the lithospheric mantle. The lithosphere of the southeastern China is dominated by peridotite or lherzolite $[1,2]$. The spinel peridotite xenoliths studied are from Fangshan basalt, eastern China, which are composed of olivine, clinopyroxene, orthopyroxene and spinel with some interstitial phases (Fig. 1). Previous studies of the mantle xenoliths indicated that the lithospheric mantle has undergone partial melting and metasomatism [1]. A significant feature of these mantle xenoliths is that they often have asymmetric symplectitic textures along rims of minerals such as clinopyroxene [3] and spinel (Fig. 2). Symplectite is a textural term that generally refers to 1) intergrowth of minerals along the rims of other minerals, 2) a breakdown product of primary phases such as garnet, pyroxene or spinel, or 3) reaction products between minerals and fluids/melts [4, 5, 6].

It was previously suggested that the symplectites in the studied xenoliths were caused by infiltration of alkali-rich fluids ( $\mathrm{Na}, \mathrm{K}, \mathrm{Fe}$, etc.) into the spinel peridotite [7]. However, backscattered electron (BSE) imaging and X-ray mapping of a sample where the xenolith neighbors with the host basalt shows that the symplectitic rims in the xenolith are often well-developed when facing to the host rock basalt. These new data show that asymmetric symplectitic textures of spinels (Fig. $2 \& 3$ ) were likely formed by reaction between the spinel peridotite xenoliths and the host basaltic melt, implying that they formed after the spinel peridotite xenoliths were sampled by the basaltic magma. A recent study suggested that the mantle xenoliths in the host basaltic magma underwent low pressure melting during ascent of the basaltic magma, resulting in formation of the low-Ca alkaline basalts [3]. However, extent and degree of assimilation and melting of the xenolith during ascent remains unknown. Further studies such as strain and orientation mapping of minerals in the xenoliths using EBSD will help better understand relations between xenoliths and their host rock basalt.

\section{References:}

[1] X. Xu et al., Chemical Geology 198 (2003), p. 163.

[2] R. Qiu et al., in "The Composition and Evolution of Continental Lithosphere in China", ed, R. Qiu et al.,Geological Publishing House, Beijing (2006), ISBN 7-116-04935-5, p. 186.

[3] G. Zeng et al., Geochemistry, Geophysics, Geosystems 14 (2013), p. 1660.

[4] R. Kretz. Metamorphic Crystallization, John Wiley \& Sons, Inc, New York (1994), pp. 507.

[5] M. Obata, Mineralogy and Petrology 101 (2011), p. 217.

[6] M. Obata in "New Frontiers in Tectonic Research - General Problems, Sedimentary Basins and Island Arcs”, ed. EV Sharkov, InTech (2011), ISBN 978-953-307-595-2, pp. 350.

[7] D. Zhao et al., GSA-SC Annual Meeting Abstracts with Programs (2013). 

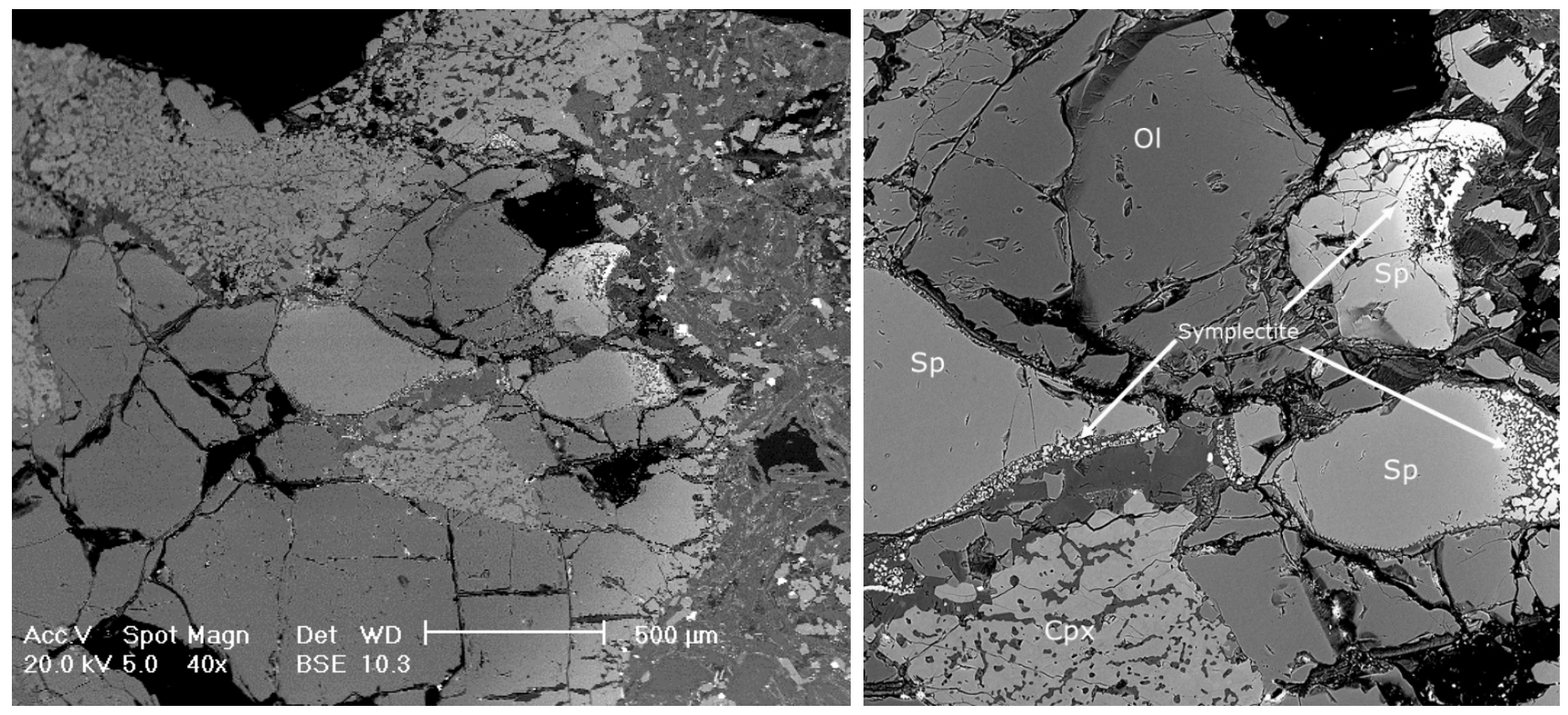

Fig. 1 (top left).

Backscattered

electron (BSE) image of a coarse-grained spinel peridotite xenolith (left) adjacent to the host basalt (right) which has fine-grained crystals.

Fig. 2 (top right). BSE image of the central area in Fig. 1. $\mathrm{Ol}-$ olivine; $\mathrm{Sp}$ - spinel; Cpx - clinopyroxene.

Fig. 3 (left). WDS $\mathrm{X}$-ray mapping of the same area as in Fig. 2 for the spinel peridotite xenolith.

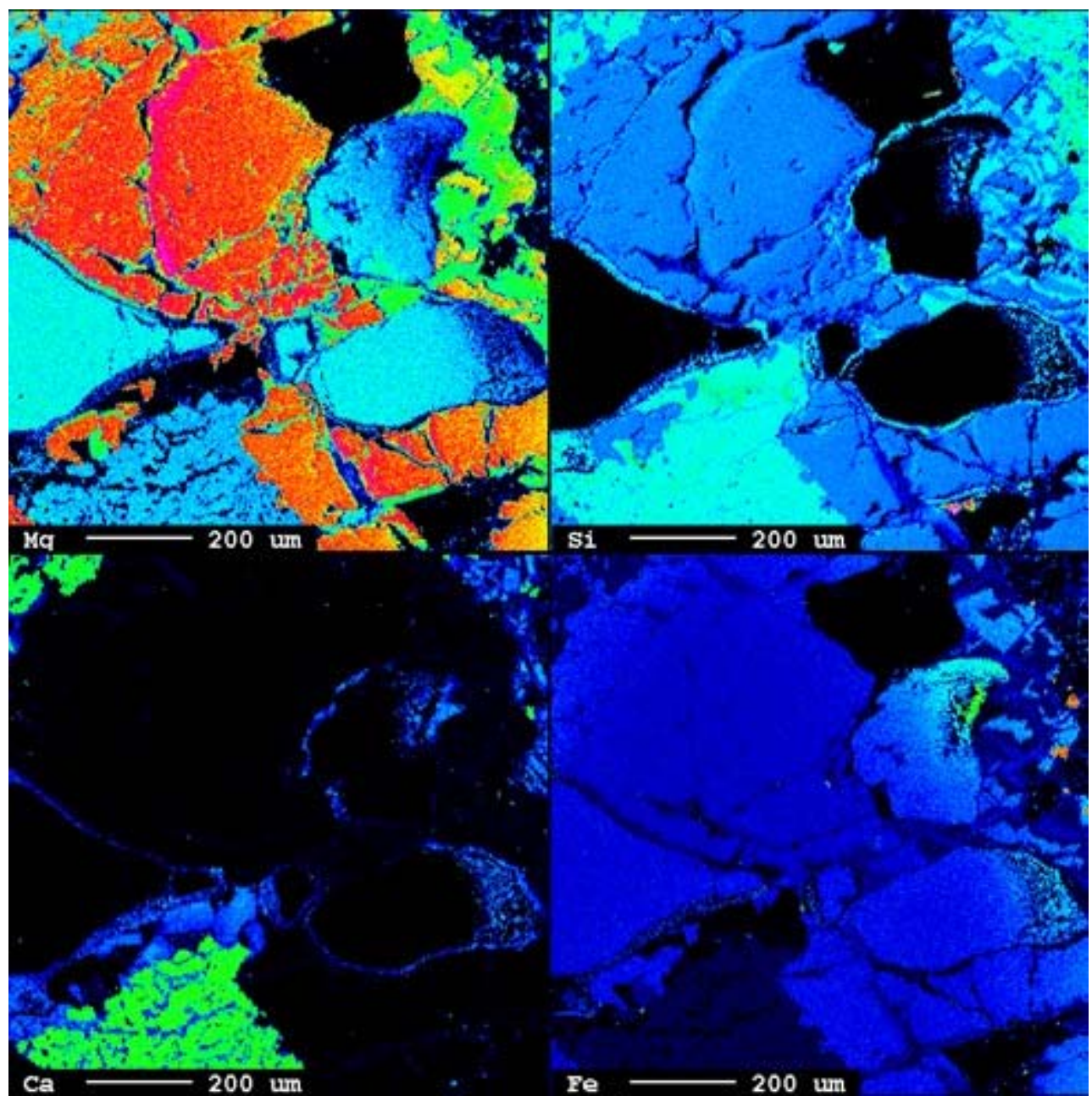

